\title{
Sağlık Bilimleri Fakültesi Öğrencilerinin Flört Şiddetine Yönelik Tutumlarının Değerlendirilmesi
}

\author{
Şengül CANGÜR 國, Tuğçe BAŞVER 國, Büşra TEMÜR ${ }^{2}{ }^{2}$, Sedef ODABAŞ ${ }^{2}$, Feyzanur \\ DEMIR ${ }^{2}$, Sümeyra KILIÇ 团 ${ }^{2}$, Betül AKAY 國, Melike GENÇ ${ }^{2}$, Büşra TAŞKIN ${ }^{2}$, \\ Beyza DIRI ${ }^{2}$
}

Öz

Amaç: Bu araştırma Düzce Üniversitesi Sağlık Bilimleri Fakültesi öğrencilerinin flört şiddetine yönelik tutumlarını belirlemek ve etkileyen etmenleri incelemek amacıyla kesitsel ve korelasyonel tipte hazırlanmıştır.

Gereç ve Yöntemler: Araştırma örneklemini oluşturan toplam 313 öğrencinin verileri kişisel bilgi formu ve Flörtte Şiddete Yönelik Tutum Ölçekleri (erkeğin ve kadının flörtte uyguladıkları psikolojik ve fiziksel şiddete yönelik tutum ölçekleri) ile elde edilmiştir. Veri türüne ve test varsayımlarının sağlanmasına göre uygun istatistiksel testler uygulanmıştır.

Bulgular: Çalışmaya katılan öğrencilerin \%50,5'i flört ilişkisinin olduğunu, \%19’u flört ilişkilerinde şiddete maruz kaldığını ve \%14,6'sı flört ilişkilerinde şiddet uyguladığını bildirmişlerdir. Araştırmada cinsiyete, kalınan yere, aile tipine, ailenin gelir düzeyine göre flört şiddetine yönelik en az bir tutum ölçek puan dağılımı açısından anlamlı düzeyde bir fark saptanırken (her biri için p $<0,05$ ), sınıfa, en uzun yaşanılan yere, kardeş sayısına, anne ve babanın eğitim düzeylerine göre anlamlı düzeyde bir fark saptanmamıştır. Ayrıca flört ilişki durumu, flört ilişkilerinde şiddete maruz kalma durumu, flört ilişkilerinde şiddet uygulama durumu ve aile içi şiddete maruz kalma durumuna göre her bir flört şiddetine yönelik tutum ölçek puan dağılımı açısından anlamlı düzeyde fark bulunmamıştır (her biri için p $>0,05$ ).

Sonuç: $\mathrm{Bu}$ çalışmayla üniversite öğrencilerinin flört şiddetine yönelik tutum ve davranışları belirlenerek, şiddete yönelik olumsuz tutum ve davranışlarının olumlu yönde değiştirilmesi için yapılacak planlamalara katkı sağlanacağı düşünülmektedir.

Anahtar Kelimeler: Üniversite öğrencileri; flört şiddeti; tutum.

\section{The Assessment of the Attitudes of Health Sciences Faculty Students towards Dating Violence}

\begin{abstract}
Aim: This study was prepared in a cross-sectional and correlational type to determine the attitudes of Duzce University Faculty of Health Sciences students towards dating violence and to examine the factors affecting it.

Material and Methods: The data of a total of 313 students constituting the research sample were obtained using personal information form and Attitudes towards Dating Violence Scales (the attitudes towards male and female psychological and physical dating violence scales). Appropriate statistical tests were applied according to the data type and the meeting of test assumptions.

Results: $50.5 \%$ of the students participating in the study stated that they had a dating relationship, $19 \%$ were exposed to violence in dating relationships, and $14.6 \%$ stated that they used violence in dating relationships. In the study, when a significant difference was found in terms of at least one attitude scale' score distribution towards dating violence according to gender, place of residence, family type, and income level of the family ( $<<0.05$ for each), no significant difference was found according to class, the place where they lived the longest, and the number of siblings and the education levels of the parents. In addition, there was no significant difference in terms of the distributions of each attitudes towards dating violence scales score according to the dating relationship status, exposure to violence in dating relationships, violence in dating relationships and exposure to domestic violence ( $>0.05$ for each).
\end{abstract}

1 Düzce Üniversitesi, Tıp Fakültesi, Biyoistatistik ve Tıbbi Bilișim Anabilim Dalı, Düzce, Türkiye

2 Düzce Üniversitesi, Sağlık Bilimleri Fakültesi, Sosyal Hizmet Bölümü, Düzce, Türkiye

Sorumlu Yazar / Corresponding Author: Şengül CANGÜR, e-mail: sengulcangur@duzce.edu.tr Geliş Tarihi / Received: 18.02.2021, Kabul Tarihi / Accepted: 17.04.2021 
Conclusion: With this study, it is thought to determine the attitudes and behaviors of university students towards dating violence, it will contribute to the plans to be made to change their negative attitudes and behaviors towards violence positively.

Keywords: University students; dating violence; attitude.

\section{GíRIŞ}

Son y1llarda önemli bir halk sağlığı ve sosyal bir sorun olan flört şiddeti, çiftlerin flört ilişkisinde birbirlerine karşı fiziksel, duygusal, sözel ve cinsel olarak şiddeti içerisinde aleni veya gizli olarak barındıran davranışlar uygulaması ve sosyal olarak birbirlerine kisitlamalar getirmesi olarak tanımlanmaktadır $(1,2)$. Özellikle üniversite yıllarına karşılık gelen 17-29 yaş aralığının flört şiddeti için riskli dönem olduğu ve bu dönemde istismar ve/veya şiddet davranışlarının diğer dönemlere göre çok daha fazla görüldüğü ifade edilmektedir (3). Bu tür bir şiddet bireyler tarafından öğrenilmiş kalıplar haline gelerek bireylerin yetişkinlik dönemlerine de taşınabilmesi ve hayat boyu devam edebilmesi nedeniyle de oldukça ciddi bir problem olarak karşımıza çıkmaktadır (2). Flört şiddetinin görülme sıklığı arttıkça normalleşmekte ve uygulama sıklığı da artmaktadır. Ataerkil toplum düzeni ve toplumsal cinsiyet rolleri gibi nedenlerle şiddet olarak kabul görmesi gereken bir takım davranışlar toplumumuzun bir kısmı tarafından şiddet olarak algılanmamakta, gerekli önlemler alınmamakta (4) ve sonuç olarak da şiddet kabullenilmektedir (1). Örneğin çiftlerin birbirlerini kıskanmaları ve kısıtlamalarda bulunmaları sevgi göstergesi olarak görülmekte ve şiddet olarak algılanmamaktadır. Bazı şiddet mağdurlarının, maruz kaldıkları şiddetin farkında olamamalarının bir sebebi ise maruz kaldıkları şiddet ile nasıl başa çıkabileceklerini bilmemeleridir (1,5). Flört şiddetinden çoğunlukla genç kadınlar etkilenmekte ve bu tür şiddet bütün 1rklar ve etnik gruplarda, sosyoekonomik ve kültürel seviyelerde görülebilmektedir $(6,7)$. Ancak flört şiddeti sadece erkeğin kadına uyguladığı şiddet olarak düşünülse de tam tersi de görülmektedir (5).

Genel şiddet davranışlarındaki gibi flört şiddetinin risk faktörleri olarak yaş, cinsiyet, çiftlerden birinin ya da her ikisinin alkol ve madde kullanması, çocukluk döneminde şiddete tanık olma ya da maruz kalma, toplumsal cinsiyet rolleri ve kadına uygulanan şiddetin benimsenmesi, kalınan yer, kişilik bozuklukları, depresyon, düşük gelir ve düşük akademik başarı olarak sıralanabilmektedir (5,79). Yapılan çalışmalarda da flört şiddetinin akut veya kronik olarak travma sonrası stres bozukluğu, somatik ve psikosomatik belirtiler, depresyon, anksiyete, uyku bozuklukları, yeme bozuklukları, utanç, suçluluk, intihar, öfke patlamaları, üzüntü ve benlik saygısının azalması, sigara, alkol ve madde kullanımları, cinsel yolla bulaşan hastalıklar gibi fiziksel ve psikolojik sonuçlara neden olabildiği saptanmıştır $(8,10-14)$.

Flört şiddetine yönelik literatür incelendiğinde özellikle ülkemizde üniversite öğrencilerinde yapılmış flört şiddeti, flört şiddetine yönelik tutum ve davranışlarını içeren sınırlı sayıda çalışma olsa da son yıllarda yapılan çalışmaların arttığı gözlenmiştir (8,15-29). Bu nedenle bu araştırmada, Düzce Üniversitesi Sağlık Bilimleri Fakültesi öğrencilerinin flört şiddetine yönelik tutumlarını belirlemek ve etkileyen etmenleri incelemek amaçlanmıştır.

\section{GEREÇ VE YÖNTEMLER \\ Araştırma Tipi}

$\mathrm{Bu}$ araştırma Düzce Üniversitesi Sağlık Bilimleri Fakültesi öğrencilerinin flört şiddetine yönelik tutumlarını değerlendirmek için kesitsel ve korelasyonel tipte hazırlanmıştır.

\section{Araştırma Popülasyonu ve Örneklemi}

$\mathrm{Bu}$ araştırmanın popülasyonu 2019-2020 eğitim-öğretim y1lında Düzce Üniversitesi Sağlık Bilimleri Fakültesi Sosyal Hizmet ve Hemşirelik bölümlerinde öğrenim gören öğrencilerin tamamıdır. $\% 95$ güven düzeyinde, $\% 5$ hata payı ve \%50 anket yanitlama oranı ile toplam 1164 öğrencinin oluşturduğu popülasyondan orantılı tabakalı örnekleme yöntemi kullanılarak, her bir bölümden rastgele seçilen ve çalışmaya katılmayı kabul eden toplam 313 öğrenci alarak araştırma örneklemi oluşturulmuştur.

\section{Veri Toplama Araçları}

Araştırmanın verileri araştırmacılar tarafından literatür bilgileri doğrultusunda oluşturulan, üniversite öğrencilerinin bazı tanıtıcı özelliklerini içeren kişisel bilgi formu ve "Flört Şiddetine Yönelik Tutum Ölçekleri" aracılığıyla toplanmıştır. Veri toplama araçları araştırmaya katılmaya gönüllü olan öğrencilere elektronik anket yoluyla uygulanmıştır.

Kişisel Bilgi Formu: Bu formda öğrencilerin cinsiyet, yaş, sınıf, medeni durum, en uzun süre yaşanılan yer, kalınan yer, aile tipi, kardeş sayısı, anne ve babanın eğitim düzeyleri, gelir düzeyi, flört ilişki durumu, ailede ve flört ilişkilerinde şiddet (fiziksel, duygusal, ekonomik ya da cinsel şiddet) uygulama/şiddete maruz kalma durumları ile ilgili sorular yer almaktadır.

Flört Şiddetine Yönelik Tutum Ölçekleri: Ölçekler, "Erkeğin Flörtte Uyguladığı Psikolojik Şiddete Yönelik Tutum Ölçeği (EFUPŞ-TÖ)", "Erkeğin Flörtte Uyguladığ1 Fiziksel Flört Şiddete Yönelik Tutum Ölçeği (EFUFŞ-TÖ)", "Kadının Flörtte Uyguladığı Psikolojik Şiddete Yönelik Tutum Ölçeği (KFUPŞ-TÖ)", "Kadının Flörtte Uyguladığı Fiziksel Şiddete Yönelik Tutum Ölçeği (KFUFŞ-TÖ)" şeklinde dört ölçekten ve toplam 50 maddeden oluşmaktadır. $\mathrm{Bu}$ ölçekler kadın ve erkeklerin flört ilişkisinde uygulanan fiziksel, psikolojik ve cinsel şiddete yönelik tutumlarını belirlemek üzere Price ve arkadaşları (30) tarafından geliştirilmiş, Yumuşak ve Şahin (31) tarafından Türkçe'ye uyarlanmıştır. Ölçeklerde yer alan maddeler için beşli likert tipi bir derecelendirme (1:Kesinlikle katılmıyorum, 2:Katılmıyorum, 3:Kararsızım, 4:Katıliyorum, 5:Kesinlikle katılıyorum) kullanılmıştır. Yüksek ölçek puanları flört şiddetine yönelik kabul düzeylerinin de yüksek olduğunu göstermektedir. Yumuşak ve Şahin (31), çalışmalarında EFUPŞ-TÖ, EFUFŞ-TÖ, KFUPŞTÖ ve KFUFŞ-TÖ şeklinde siralan bu dört ölçeğin Cronbach alfa değerlerini sirasiyla $0,81,0,87,0,75,0,87$ olarak bulmuşlardır.

\section{Araştırmanın Etik Yönü}

Araştırma ve yayın etiği kurallarına uyularak hazırlanan bu çalışmada uygulamanın yapılabilmesi için Düzce Üniversitesi Bilimsel Araştırma ve Yayın Etik Kurulundan (05/12/2019, 2019/97) ve Düzce Üniversitesi Sağlık Bilimleri Fakültesi Dekanlığından (23/12/2019, 
88606300/605.01/) gerekli izinler alınmıştır. Ayrıca çalışmaya katılmayı kabul eden öğrencilere araştırmanın amacıyla ilgili bilgi verilmiş ve onayları alınmıştır.

\section{İstatistiksel Analiz}

Tüm verilerin uygun tanımlayıcı istatistikleri hesaplanmıştır. Nicel değişkenlerin normallik varsayım kontrolü Kolmogorov Smirnov ve Shapiro Wilk testleriyle, varyansların homojenliği varsayım kontrolü ise Levene testiyle incelenmiştir. Gruplar arası karşılaştırmalarda Kruskal Wallis (post hoc Dunn testi) ve Mann-Whitney U testleri kullanılmıştır. Ölçeklerin güvenirlik analizi için Cronbach alfa katsayıları hesaplanmıştır. Oran karşılaştırmalarında Binomial ve Chi-square testlerinden yararlanılmıștır. Kategorik değişkenler arasındaki ilişkiler ise Pearson Chi-square testi (post hoc Bonferroni testi) ile incelenmiştir. İstatistiksel değerlendirmelerin tümü SPSS 22 programında yapılmıştır. $\mathrm{p}<0,05$ istatistiksel olarak anlamlı kabul edilmiştir.

\section{BULGULAR}

Çalışmaya katılan toplam 313 öğrencinin yaş ortalaması 21,2 $\pm 1,9$ 'dur. $\mathrm{Bu}$ öğrencilerin \%52,1'i kadın, \%31,6's1 dördüncü sinıfta ve \%44'ü sosyal hizmet bölümünde öğrenim görmekte ve \%50,8'i ise ailesiyle yaşamaktadır. Katılımcıların sosyo-demografik özelliklerine göre dağılımları Tablo 1'de verilmiştir.

Çalışmaya alınan öğrencilerin cinsiyet, devam edilen sınıf ve bölüm açısından homojen oldukları saptanmıştır (sırasıyla $p=0,498 p=0,051 \quad p=0,054)$ ). Öğrencilerin $\% 50,5$ 'i bir flört ilişskisinin olduğunu, \%19'u flört ilişkilerinde şiddete (fiziksel, duygusal, ekonomik ya da cinsel şiddet) maruz kaldığını, \%14,6'sı flört ilişkilerinde şiddet uyguladığını ve \%19,5'i aile içi şiddete maruz kaldığını bildirmişlerdir. Çalışmadaki öğrencilerin flört ilişkisi, şiddete maruz kalma/şiddet uygulama durumlarıyla ilgili özellikleri Tablo 2'de verilmiştir. Öğrencilere uygulanan her bir flört şiddetine yönelik tutum ölçeklerine ait tanımlayıcı istatistikler ve Cronbach alfa değerleri Tablo 3'te verilmiştir. Erkeğin flörtte uyguladığı psikolojik ve fiziksel şiddete yönelik tutum ölçeklerine ait ortalama puanlar sırasıyla $27,6 \pm 9,6$ ve $17,6 \pm 7,2$ iken kadının flörtte uyguladığ 1 psikolojik ve fiziksel şiddete yönelik tutum ölçeklerine ait ortalama puanlar $19,3 \pm 7,7$ ve $28 \pm 3,8$ 'dir. Cronbach alfa değerlerine göre EFUPŞ-TÖ, EFUFŞ-TÖ ve KFUPŞTÖ'nün iyi düzeyde, KFUFŞ-TÖ'nün ise kabul edilebilir düzeyde güvenirliğe sahip oldukları söylenebilir.

Sosyo-demografik özelliklere göre her bir flört şiddetine yönelik tutum ölçek puanının tanımlayıcı istatistikleri ve karşılaştırma sonuçları Tablo 4'te verilmiştir. Cinsiyete göre her bir flört şiddetine yönelik tutum ölçek puan dağılımları açısından anlamlı düzeyde fark saptanmıştır (her biri için $\mathrm{p}<0,05$ ). Kadınların flört şiddetine yönelik geliştirilen her bir tutum ölçek puan dağılımı, erkeklerinkinden anlamlı düzeyde daha düşüktür.

Kalınan yere (yurt, aile, arkadaş, diğer) göre erkeğin flörtte uyguladığı psikolojik şiddete yönelik tutum ölçek puan dağılımı açısından anlamlı düzeyde fark bulunmuştur $(\mathrm{p}<0,05)$. Evde arkadaşlarıyla birlikte kalan öğrencilerin erkeğin flörtte uyguladığı psikolojik şiddete yönelik tutum ölçek puanı, yurtta, ailesiyle birlikte ve diğer (akraba vb.) olarak nitelendiren yerde kalan öğrencilerinkinden anlamlı düzeyde daha yüksektir (sirasiyla $p=0,016 p=0,016 p=0,020)$. Ancak kalınan yere göre erkeğin flörtte uyguladığı fiziksel şiddete yönelik tutum, kadının flörtte uyguladığı hem psikolojik hem de fiziksel şiddete yönelik tutum ölçek puanları bakımından anlamlı düzeyde bir fark yoktur (her biri için $p>0,05$ ).

Tablo 1. Öğrencilerin sosyo-demografik özellikleri

\begin{tabular}{|c|c|c|c|}
\hline \multicolumn{2}{|l|}{ Özellikler } & \multirow{2}{*}{$\begin{array}{c}\mathbf{n} \\
163\end{array}$} & \multirow{2}{*}{$\begin{array}{c}\% \\
52,1\end{array}$} \\
\hline \multirow{2}{*}{ Cinsiyet } & Kadın & & \\
\hline & Erkek & 150 & 47,9 \\
\hline \multirow{2}{*}{ Bölüm } & Sosyal Hizmet & 139 & 44 \\
\hline & Hemşirelik & 174 & 56 \\
\hline \multirow{4}{*}{ Sinıf } & 1 & 68 & 21,7 \\
\hline & 2 & 70 & 22,4 \\
\hline & 3 & 76 & 24,3 \\
\hline & 4 & 99 & 31,6 \\
\hline \multirow{2}{*}{ Medeni durum } & Bekâr & 311 & 99,4 \\
\hline & Evli & 2 & 0,6 \\
\hline \multirow{2}{*}{$\begin{array}{l}\text { En uzun süre } \\
\text { yaşanılan yer }\end{array}$} & Köy/Kasaba/İlçe & 104 & 33,2 \\
\hline & İl & 209 & 66,8 \\
\hline \multirow{4}{*}{ Kalınan yer } & Yurt & 96 & 30,7 \\
\hline & Aile & 159 & 50,8 \\
\hline & Arkadaş & 52 & 16,6 \\
\hline & Diğer & 6 & 1,9 \\
\hline \multirow{3}{*}{ Kardeş sayısı } & Yok & 19 & 6,1 \\
\hline & 1-3 & 260 & 83,1 \\
\hline & 4 ve üzeri & 34 & 10,9 \\
\hline \multirow{3}{*}{ Aile tipi } & Çekirdek & 251 & 80,2 \\
\hline & Geniş & 46 & 14,7 \\
\hline & Tek ebeveynli & 16 & 5,1 \\
\hline \multirow{5}{*}{$\begin{array}{l}\text { Anne eğitim } \\
\text { düzeyi }\end{array}$} & \begin{tabular}{|l|}
$\begin{array}{l}\text { Okuma yazması } \\
\text { yok }\end{array}$ \\
\end{tabular} & 14 & 4,5 \\
\hline & \begin{tabular}{|l|} 
İlkokul \\
\end{tabular} & 132 & 42,2 \\
\hline & \begin{tabular}{|l|} 
Ortaokul \\
\end{tabular} & 70 & 22,4 \\
\hline & Lise & 0 & 0 \\
\hline & Üniversite ve üzeri & 97 & 31 \\
\hline \multirow{5}{*}{ Baba eğitim düzeyi } & \begin{tabular}{|l|} 
Okuma yazması \\
yok
\end{tabular} & 1 & 0,3 \\
\hline & \begin{tabular}{|l|} 
İlkokul \\
\end{tabular} & 88 & 28,1 \\
\hline & Ortaokul & 73 & 23,3 \\
\hline & Lise & 0 & 0 \\
\hline & \begin{tabular}{|l|l|} 
Üniversite ve üzeri \\
\end{tabular} & 151 & 48,2 \\
\hline \multirow{3}{*}{$\begin{array}{l}\text { Ailenin gelir } \\
\text { düzeyi }\end{array}$} & 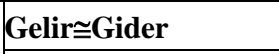 & 203 & 64,9 \\
\hline & \begin{tabular}{|l|} 
Gelir>Gider \\
\end{tabular} & 68 & 21,7 \\
\hline & Gelir< Gider & 42 & 13,4 \\
\hline
\end{tabular}

Aile tipine (çekirdek, geniş, tek ebeveynli) göre erkeğin flörtte uyguladığı psikolojik şiddete yönelik tutum ölçek puanları bakımından anlamlı düzeyde fark saptanmıştır $(p<0,05)$. Tek ebeveynli öğrencilerin erkeğin flörtte uyguladığı psikolojik şiddete yönelik tutum ölçek puanı, çekirdek ve geniş ailelere sahip öğrencilerinkinden anlamlı düzeyde daha düşüktür (sırasıyla $p=0,009$ $\mathrm{p}=0,005)$. Ancak aile tipine göre erkeğin flörtte uyguladığı fiziksel şiddete yönelik tutum, kadının flörtte uyguladığı hem psikolojik hem de fiziksel şiddete yönelik 
tutum ölçek puanları açısından anlamlı düzeyde bir fark yoktur (her biri için $\mathrm{p}>0,05$ ).

Tablo 2. Öğrencilerin flört ilişkisi, şiddet uygulama/şiddete maruz kalma durumlarıyla ilgili özellikleri

\begin{tabular}{|l|l|c|c|}
\hline \multicolumn{2}{|l|}{} & n & \% \\
\hline \multirow{2}{*}{ Flört ilişki durumu } & Evet & 158 & 50,5 \\
\cline { 2 - 4 } & Hayır & 155 & 49,5 \\
\hline \multirow{3}{*}{$\begin{array}{l}\text { Flört ilişkilerinde şiddete } \\
\text { maruz kalma durumu }\end{array}$} & Evet & 30 & 19 \\
\cline { 2 - 4 } & Hayır & 106 & 67,1 \\
\cline { 2 - 4 } & Kararsızım & 22 & 13,9 \\
\hline \multirow{2}{*}{$\begin{array}{l}\text { Flört ilişkilerinde şiddet } \\
\text { uygulama durumu }\end{array}$} & Evet & 23 & 14,6 \\
\cline { 2 - 4 } & Hayır & 111 & 70,3 \\
\cline { 2 - 4 } & Kararsızım & 24 & 15,2 \\
\hline $\begin{array}{l}\text { Aile içi şiddete maruz kalma } \\
\text { durumu }\end{array}$ & Evet & 61 & 19,5 \\
\cline { 2 - 4 } & Hayır & 252 & 80,5 \\
\hline
\end{tabular}

Tablo 3. Öğrencilere uygulanan flört şiddetine yönelik tutum ölçeklerine ait tanımlayıcı istatistikler ve Cronbach alfa değerleri

\begin{tabular}{|l|c|c|c|c|}
\hline & $\begin{array}{c}\text { EFUPŞ- } \\
\text { Tö } \\
\text { puanı }\end{array}$ & $\begin{array}{c}\text { EFUFŞ } \\
\text {-TÖ } \\
\text { puanı }\end{array}$ & $\begin{array}{c}\text { KFUPŞ } \\
\text {-TÖ } \\
\text { puanı }\end{array}$ & $\begin{array}{c}\text { KFUFŞ- } \\
\text { TÖ } \\
\text { puanı }\end{array}$ \\
\hline Ort \pm SS & $27,6 \pm 9,6$ & $17,6 \pm 7,2$ & $19,3 \pm 7,7$ & $28 \pm 3,8$ \\
\hline Ortanca & 25 & 15 & 18 & 28 \\
\hline ÇAG & 15 & 9 & 12 & 4 \\
\hline $\begin{array}{l}\text { Değişim } \\
\text { Aralığı }\end{array}$ & 45 & 36 & 40 & 24 \\
\hline $\begin{array}{l}\text { Cronbach } \\
\text { alfa }\end{array}$ & 0,85 & 0,86 & 0,87 & 0,72 \\
\hline
\end{tabular}

EFUPS-TÖ: Erkeğin flörtte uyguladığı psikolojik siddete yönelik tutum ölçeği, EFUFS-TÖ: Erkeğin flörtte uyguladı̆̆ fiziksel siddete yönelik tutum ölçeğ $\mathrm{i}$, KFUPŞ-TÖ: Kadının flörtte uyguladığı psikolojik şiddete yönelik tutum ölçeği, KFUFŞ-TÖ: Kadının flörtte uyguladığı fiziksel şiddete yönelik tutum ölçeği, Ort \pm SS: Ortalama \pm Standart Sapma; CAG: Ceyrekler Arası Genișlik

Tablo 4. Sosyo-demografik özelliklere öğrencilerin göre her bir flört şiddetine yönelik tutum ölçek puanının tanımlayıcı istatistikleri ve karşılaştırma sonuçları

\begin{tabular}{|c|c|c|c|c|c|c|c|c|c|c|c|}
\hline & \multirow[b]{2}{*}{$\mathbf{n}$} & \multicolumn{2}{|c|}{$\begin{array}{c}\text { EFUPŞ-TÖ* } \\
\text { puanı }\end{array}$} & \multicolumn{2}{|c|}{$\begin{array}{c}\begin{array}{c}\text { EFUFŞ-TÖÖ } \\
\text { puanı }\end{array} \\
\end{array}$} & \multicolumn{2}{|c|}{$\begin{array}{c}\text { KFUPŞ-TÖ }^{\$} \\
\text { puanı }\end{array}$} & \multicolumn{2}{|c|}{$\begin{array}{c}\text { KFUFŞ-TÖ }^{\mathfrak{e}} \\
\text { puanı }\end{array}$} & \multirow[t]{2}{*}{$\mathbf{p}$} \\
\hline & & & $\mathbf{M}$ & CAG & $\mathbf{M}$ & CAG & $\mathbf{M}$ & CAG & $\mathbf{M}$ & CAG & \\
\hline \multirow{2}{*}{ Cinsiyet } & Kadın & 163 & 22 & 9 & 13 & 4 & 16 & 10 & 28 & 4 & \multirow{2}{*}{$<0,001^{* \text { *St }}$} \\
\hline & \begin{tabular}{|l|} 
Erkek \\
\end{tabular} & 150 & 32 & 16 & 16 & 14 & 21 & 11 & 28 & 3 & \\
\hline \multirow[t]{2}{*}{ Bölüm } & Sosyal Hizmet & 139 & 25 & 15 & 14 & 7 & 19 & 11 & 28 & 3 & $\begin{array}{l}0,994^{*} \\
0,421^{\#} \\
0,630^{\$}\end{array}$ \\
\hline & \begin{tabular}{|l|} 
Hemşirelik \\
\end{tabular} & 174 & 26 & 15 & 16 & 9 & 18 & 11 & 28 & 4 & $0,523^{\mathfrak{E}}$ \\
\hline \multirow{4}{*}{ Sinif } & 1 & 68 & 27 & 16 & 16 & 8,5 & 20 & 9,5 & 28 & 4 & \multirow{4}{*}{$\begin{array}{l}0,092^{*} \\
0,129^{\#} \\
0,464^{\$} \\
0,533^{\natural}\end{array}$} \\
\hline & 2 & 70 & 24 & 13 & 14 & 8 & 17,5 & 12 & 28 & 3 & \\
\hline & 3 & 76 & 24 & 13 & 13 & 6 & 16 & 12,5 & 28 & 2,5 & \\
\hline & 4 & 99 & 27 & 18 & 16 & 10 & 18 & 11 & 28 & 5 & \\
\hline \multirow{2}{*}{$\begin{array}{l}\text { En uzun süre } \\
\text { yaşanılan yer }\end{array}$} & $\begin{array}{l}\text { Köy/Kasaba } \\
\text { /İlçe }\end{array}$ & 104 & 25 & 15,5 & 14 & 8 & 16,5 & 11 & 28 & 4 & \multirow{2}{*}{$\begin{array}{l}0,422^{*} \\
0,407^{\#} \\
0,296^{\S} \\
0,262^{£}\end{array}$} \\
\hline & İl & 209 & 26 & 15 & 15 & 9 & 19 & 12 & 28 & 3 & \\
\hline \multirow{4}{*}{ Kalınan yer } & Yurt & 96 & 25 & 15 & 13 & 7,5 & 17 & 11 & 28 & 4 & \multirow{4}{*}{$\begin{array}{l}0,002^{*} \\
0,133^{\#} \\
0,477^{\S} \\
0,483^{\mathfrak{E}}\end{array}$} \\
\hline & \begin{tabular}{|l|} 
Aile \\
\end{tabular} & 159 & 25 & 12 & 15 & 9 & 18 & 11 & 28 & 4 & \\
\hline & \begin{tabular}{|l|} 
Arkadaş \\
\end{tabular} & 52 & 32 & 17 & 16 & 14 & 20 & 12 & 28 & 3 & \\
\hline & Diğer & 6 & 21 & 2 & 13,5 & 3 & 19,5 & 13 & 28,5 & 1 & \\
\hline \multirow{3}{*}{ Kardeş sayısı } & Yok & 19 & 27 & 20 & 13 & 4 & 15 & 10 & 28 & 2 & \multirow{3}{*}{$\begin{array}{l}0,598^{*} \\
0,377^{\#} \\
0,356^{\S} \\
0,318^{£}\end{array}$} \\
\hline & $1-3$ & 260 & 25 & 14 & 15 & 8 & 19 & 11,5 & 28 & 4 & \\
\hline & 4 ve üzeri & 34 & 27,5 & 15 & 14 & 11 & 19,5 & 11 & 28 & 5 & \\
\hline \multirow{3}{*}{ Aile tipi } & Çekirdek & 251 & 25 & 15 & 15 & 8 & 19 & 12 & 28 & 4 & \multirow{3}{*}{$\begin{array}{l}0,006^{*} \\
0,213^{\#} \\
0,126^{\S} \\
0,195^{£}\end{array}$} \\
\hline & Geniş & 46 & 27,5 & 18 & 16 & 12 & 19,5 & 10 & 28 & 4 & \\
\hline & Tek ebeveynli & 16 & 20,5 & 6 & 12,5 & 5 & 15 & 6,5 & 28 & 3 & \\
\hline \multirow{4}{*}{$\begin{array}{l}\text { Anne eğitim } \\
\text { düzeyi }\end{array}$} & OD & 14 & 27,5 & 16 & 20,5 & 8 & 17,5 & 10 & 28 & 1 & \multirow{4}{*}{$\begin{array}{l}0,521^{*} \\
0,050^{\#} \\
0,722^{\$} \\
0,052^{\mathfrak{E}}\end{array}$} \\
\hline & İlkokul & 132 & 25 & 13 & 13,5 & 7,5 & 18 & 11 & 28 & 3 & \\
\hline & Ortaokul & 70 & 27,5 & 17 & 16 & 12 & 18 & 12 & 28 & 4 & \\
\hline & \begin{tabular}{|l|} 
Üniversite ve \\
üzeri \\
\end{tabular} & 97 & 25 & 14 & 15 & 8 & 19 & 11 & 28 & 3 & \\
\hline \multirow{4}{*}{$\begin{array}{l}\text { Baba eğitim } \\
\text { düzeyi }\end{array}$} & OD & 1 & 23 & 0 & 14 & 0 & 18 & 0 & 29 & 0 & \multirow{4}{*}{$\begin{array}{l}0,789^{*} \\
0,905^{\#} \\
0,402^{\S} \\
0,711^{\mathfrak{E}}\end{array}$} \\
\hline & İlkokul & 88 & 25 & 14 & 14 & 8 & 16,5 & 12 & 28 & 2 & \\
\hline & \begin{tabular}{|l|} 
Ortaokul \\
\end{tabular} & 73 & 25 & 14 & 16 & 10 & 21 & 10 & 28 & 5 & \\
\hline & $\begin{array}{l}\text { Üniversite ve } \\
\text { üzeri }\end{array}$ & 151 & 26 & 15 & 14 & 9 & 18 & 12 & 28 & 4 & \\
\hline \multirow{3}{*}{$\begin{array}{l}\text { Ailenin gelir } \\
\text { düzeyi }\end{array}$} & Gelir $\cong$ Gider & 203 & 25 & 14 & 14 & 8 & 16 & 11 & 28 & 3 & \multirow{3}{*}{$\begin{array}{l}0,089^{*} \\
0,149^{\#} \\
0,020^{\$} \\
0,698^{£}\end{array}$} \\
\hline & Gelir>Gider & 68 & 28,5 & 17,5 & 16 & 11,5 & 21 & 9,5 & 28 & 4 & \\
\hline & Gelir<Gider & 42 & 26,5 & 13 & 16 & 9 & 21,5 & 8 & 28 & 5 & \\
\hline
\end{tabular}

EFUPŞ-TÖ: Erkeğin flörtte uyguladığı psikolojik șiddete yönelik tutum ölçeği, EFUFŞ-TÖ: Erkeğin flörtte uyguladığı fiziksel șiddete yönelik tutum ölçeği, KFUPŞ-TÖ: Kadının flörtte uyguladığı psikolojik şiddete yönelik tutum ölçeği, KFUFŞ-TÖ: Kadının flörtte uyguladığı fiziksel şiddete yönelik tutum ölçeği, OD: Okuryazar değil, M: Medyan, ÇAG: Çeyrekler Arası Genişlik 
Ailenin gelir düzeyine (gelir@gider, gelir>gider, gelir<gider) göre kadının flörtte uyguladığı psikolojik şiddete yönelik tutum ölçek puan dağılımı açısından anlamlı düzeyde fark saptanmıştır $(p<0,05)$. Geliri giderinden az olan öğrencilerin kadının flörtte uyguladığı psikolojik şiddete yönelik tutum ölçek puanı, geliri giderine denk olan öğrencilerinkinden anlamlı düzeyde daha yüksektir $(\mathrm{p}=0,030)$. Ancak ailenin gelir düzeyine göre erkeğin flörtte uyguladığı hem psikolojik hem de fiziksel şiddete yönelik tutum, ayrıca kadının flörtte uyguladığı fiziksel şiddete yönelik tutum ölçek puanları açısından anlamlı düzeyde bir fark yoktur (her biri için $\mathrm{p}>0,05)$.

Tablo 5. Flört ilişkisi, şiddete maruz kalma/şiddet uygulama durumlarına göre öğrencilerin her bir flört şiddetine yönelik tutum ölçek puanlarına ait tanımlayıcı istatistikler ve karşılaştırma sonuçları

\begin{tabular}{|c|c|c|c|c|c|c|c|c|c|c|c|}
\hline & \multirow[b]{2}{*}{$\mathbf{n}$} & \multicolumn{2}{|c|}{$\begin{array}{c}\text { EFUPŞ-TÖ* } \\
\text { puanı }\end{array}$} & \multicolumn{2}{|c|}{$\begin{array}{c}\text { EFUFŞ-TÖ }^{\#} \\
\text { puanı }\end{array}$} & \multicolumn{2}{|c|}{$\begin{array}{c}\text { KFUPŞ-TÖ } \\
\text { puanı }\end{array}$} & \multicolumn{2}{|c|}{$\begin{array}{c}\text { KFUFŞ-TÖ }^{£} \\
\text { puanı }\end{array}$} & \multirow[t]{2}{*}{$\mathbf{p}$} \\
\hline & & & $\mathbf{M}$ & ÇAG & $\mathbf{M}$ & ÇAG & $\mathbf{M}$ & ÇAG & $\mathbf{M}$ & ÇAG & \\
\hline \multirow{2}{*}{ Flört ilişki durumu } & Evet & 158 & 25,5 & 15 & 14 & 6 & 19 & 11 & 28 & 3 & \multirow{2}{*}{$\begin{array}{c}0,898^{*} \\
0,133^{\#} \\
0,442^{\$} \\
0,070\end{array}$} \\
\hline & Hayır & 155 & 25 & 15 & 16 & 10 & 17 & 12 & 28 & 3 & \\
\hline \multirow{3}{*}{$\begin{array}{l}\text { Flört ilişkilerinde } \\
\text { şiddete maruz } \\
\text { kalma durumu }\end{array}$} & Evet & 30 & 24,5 & 10 & 13 & 6 & 17 & 10 & 28 & 3 & \multirow{3}{*}{$\begin{array}{l}0,296^{*} \\
0,615^{\#} \\
0,321^{\$} \\
0,784^{£}\end{array}$} \\
\hline & Hayır & 106 & 25 & 15 & 14 & 6 & 19 & 11 & 28 & 3 & \\
\hline & Kararsızım & 22 & 31 & 14 & 15 & 10 & 21,5 & 11 & 28 & 6 & \\
\hline \multirow{3}{*}{$\begin{array}{l}\text { Flört ilişkilerinde } \\
\text { şiddet uygulama } \\
\text { durumu }\end{array}$} & \begin{tabular}{|l|} 
Evet \\
\end{tabular} & 23 & 23 & 15 & 13 & 6 & 18 & 12 & 28 & 3 & \multirow{3}{*}{$\begin{array}{l}0,168^{*} \\
0,085^{\ddagger} \\
0,230^{\$} \\
0,238^{\ddagger}\end{array}$} \\
\hline & Hayır & 111 & 25 & 15 & 14 & 5 & 19 & 11 & 28 & 2 & \\
\hline & Kararsızım & 24 & 29,5 & 13 & 16,5 & 16 & 21 & 11 & 28 & 6,5 & \\
\hline \multirow{2}{*}{$\begin{array}{l}\text { Aile içi şiddete } \\
\text { maruz kalma } \\
\text { durumu }\end{array}$} & Evet & 61 & 26 & 16 & 15 & 9 & 18 & 11 & 28 & 3 & \multirow{2}{*}{$\begin{array}{l}0,610^{*} \\
0,204^{\#} \\
0,815^{\$} \\
0,894^{f}\end{array}$} \\
\hline & Hayır & 252 & 25 & 14 & 14 & 8 & 19 & 12 & 28 & 4 & \\
\hline
\end{tabular}

EFUPŞ-TÖ: Erkeğin flörtte uyguladığı psikolojik șiddete yönelik tutum ölçeği, EFUFŞ-TÖ: Erkeğin flörtte uyguladığı fiziksel șiddete yönelik tutum ölçeği, KFUPŞ-TÖ: Kadının flörtte uyguladığı psikolojik şiddete yönelik tutum ölçeği, KFUFŞ-TÖ: Kadının flörtte uyguladığı fiziksel şiddete yönelik tutum ölçeği, M: Medyan, ÇAG: Çeyrekler Arası Genişlik

Devam edilen sınıfa ve bölüme, en uzun yaşanılan yere, kardeş sayısına, anne ve babanın eğitim düzeylerine göre her bir flört şiddetine yönelik tutum ölçek puanı açısından anlamlı düzeyde fark saptanmamıştır (her biri için $\mathrm{p}>0,05)$.

Flört ilişki durumu, şiddete maruz kalma/şiddet uygulama durumlarına göre her bir flört şiddetine yönelik tutum ölçek puanlarına ait tanımlayıcı istatistikler ve karşılaştırma sonuçları Tablo 5'te verilmiştir. Öğrencilerin bu özelliklerine göre her bir flört şiddetine yönelik tutum ölçek puan dağılımı açısından anlamlı düzeyde bir fark saptanmamıştır (her biri için $p>0,05$ ). Benzer bulgular ayrıca erkek ve kadın öğrenciler için de elde edilmiştir.

Ayrıca aile içinde şiddete maruz kalma durumuna göre şu ana kadar flört ilişkisinde şiddet uyguladığını düşünüyor musunuz sorusuna verilen yanitların oranları arasında anlamlı düzeyde bir fark saptanmıştır $(p=0,045)$. Aile içi şiddete maruz kalan ve kalmayan bireylerde şu ana kadar flört ilişkisinde şiddet uyguladığını düşünenlerin oranları (sırasıyla \%18,4 \%13,3) arasında anlamlı düzeyde fark saptanmazken, aile içi şiddete maruz kalmayan bireylerin şu ana kadar flört ilişkisinde şiddet uygulamadığını düşünenlerin oranı $(\% 75)$, aile içi şiddete maruz kalanlarda gözlenen orandan $(\% 55,3)$ anlamlı düzeyde daha yüksek bulunmuştur $(\mathrm{p}<0,05)$.

\section{TARTIŞMA}

Sağlıklı toplumları oluşturmak açısından bireylerin küçük yaşlardan başlayarak genel şiddet türleri gibi flört şiddetine karşı da duyarlı olarak eğitilmeleri ve farkındalık oluşturulması sağlıklı ilişkiler kurmaları ve sürdürmeleri açısından oldukça önemlidir. Güncel haberler, sağlıklı ve bilinçli bir gelecek için şiddet türleri içerisinde flört şiddetinin de önemli bir sorun olarak ele alınması gerektiğini doğrulamaktadır. $\mathrm{Bu}$ çalışmada Düzce Üniversitesi Sağlık Bilimleri Fakültesi öğrencilerinin flört şiddetine yönelik tutumları ve etkileyen etmenler belirlenmiştir.

Araştırmada öğrencilerin \%19'u flört ilişkilerinde şiddete maruz kaldıklarını, \%14,6'sı flört ilişkilerinde şiddet uyguladıklarını bildirmişlerdir. Son yıllarda yapılmış çalışmalar incelendiğinde üniversite öğrencilerinde flört şiddeti sıklığının Brezilya'da yaklaşık \%76, Çin'de \%59, Amerika'da \%53, Kirgizistan'da \%42, Nijer'de \%18, Hindistan'da \%16 (24,29) ve Türkiye'de ise yaklaşık \%11-53 civarında olduğu görülmüştür

Araştırmada kadınların her bir flört şiddetine yönelik kabul düzeyleri, erkeklerinkinden anlamlı düzeyde daha düşük bulunmuştur. Özdere'nin (28) beden eğitimi ve spor yüksekokulu ögrencilerinde, Ayyıldız ve Taylan'ın (21) üniversite öğrencilerinde yaptıkları çalışmalarda erkeklerin her bir flört şiddetine yönelik kabul düzeylerini, kadınlarınkinden anlamlı düzeyde daha yüksek bulmuşlardır. Ayrıca Sezer ve Sumbas'ın (26) eğitim fakültesi öğrencilerinde, Şahin ve Arslan'in (25) sosyal hizmet bölümü öğrencilerinde, Karabacak ve Çetinkaya'nın (18) üniversite öğrencilerinde yaptıkları çalışmalarda erkek öğrencilerin çiftler arası şiddet kabul düzeyleri, kadın öğrencilerinkinden anlamlı düzeyde daha yüksek olduğu belirlenmiştir. Şimşek ve Kavas (22) ise üniversite öğrencilerinde yaptıkları çalışmada sadece kadınlara göre erkeklerin erkeğin flörtte uyguladığ 1 fiziksel şiddete yönelik kabul düzeylerinin daha yüksek 
olduğunu ancak diğer tutum ölçekleri açısından (erkeğin flörtte uyguladığı psikolojik şiddet, kadının flört ilişkisinde uyguladığı fiziksel ve psikolojik şiddete yönelik tutum) cinsiyete göre anlamlı bir farkl1lık olmadığını saptamışlardır. İftar (19) üniversite öğrencilerinde yaptığı çalışmada kadınlara göre erkeklerin erkeğin flört ilişkisinde uyguladığı fiziksel ve psikolojik şiddete yönelik kabul düzeylerinin yanı sıra kadının flört ilişkisinde uyguladığı psikolojik şiddete yönelik kabul düzeyinin de daha yüksek olduğunu bulmuştur. Yıldırım (20) üniversite öğrencilerinde yaptığ çalışmada kadınların erkeklere göre anlamlı düzeyde flört şiddetini desteklemeyen bir tutum sergilediklerini belirlemiştir. Anderson ve ark.'nın (13) Çin'de üniversite öğrencileri üzerinde yaptıkları çalışmada sadece kadınlara göre erkeklerin erkeğin flörtte uyguladığı psikolojik şiddete yönelik kabul düzeylerinin daha yüksek olduğunu ancak diğer tutum ölçekleri açısından cinsiyete göre anlamlı bir farklılık olmadığını saptamışlardır. Devrim'in (29) hemşirelik bölümü öğrencilerinde yaptığı çalışmada da kadın ve erkeklerin flört şiddetine yönelik tutumlarının benzer olduğu belirlenmiştir. Araştırma bulgularımızın, Özdere'nin (28), Ayyıldız ve Taylan'ın (21), Yıldırım'ın (20), Şahin ve Arslan'ın (25), Karabacak ve Çetinkaya'nın (18) çalışma sonuçlarıyla benzerlik gösterdiği, Şimşek ve Kavas'ın (22), İftar'ın (19) ve Anderson ve ark.'nın (13) çalışma sonuçlarıyla kısmen benzerlik gösterdiği ancak Devrim'in (29) çalışma sonuçlarıyla benzerlik göstermediği söylenebilir.

Öğrenim görülen bölüme göre her bir flört şiddetine yönelik kabul düzeylerinin benzer olduğu belirlenmiştir. Literatürde yapılan çalışmalar incelendiğinde genel olarak üniversite öğrencilerinin flört şiddetine yönelik kabul düzeylerinin öğrenim gördükleri fakültelere göre incelendiği gözlenmiştir $(16,17,19,20)$.

Öğrenim görülen sinıfa göre her bir flört şiddetine yönelik kabul düzeylerinin benzer olduğu saptanmıştır. Bulgularımız, Devrim'in (29) hemşirelik öğrencilerinde, Şahin ve Arslan'ın (25) sosyal hizmet bölümü ögrrencilerinde ve Kaya Sakarya'nın (17) üniversite öğrencilerinde yaptıkları çalışma sonuçlarını destekler niteliktedir. Ancak çalışma bulgularımızın tam aksine İftar'ın (19) çalışmasında 4. sınıf üniversite öğrencilerinin her bir flört şiddetine yönelik kabul düzeylerinin diğer sınıflarda öğrenim gören öğrencilerinkinden anlamlı düzeyde daha düşük olduğu bulunmuştur. Ayrıca Anderson ve ark.'nın (13) Çin'de üniversite öğrencileri üzerinde yaptıkları çalışmada üniversitedeki eğitim yılı ile sadece kadının flörtte uyguladığı psikolojik şiddete yönelik kabul düzeyi arasında anlamlı düzeyde pozitif bir ilişki saptarlarken diğer flört şiddetine yönelik kabul düzeyleri arasında anlamlı bir ilişki saptamamışlardır. Bulgularımızın kısmen de olsa Anderson ve ark.'nın (13) çalışma sonuçlarına benzer olduğu söylenebilir.

En uzun yaşanılan yere göre her bir flört şiddetine yönelik kabul düzeylerinin benzer olduğu saptanmıştır. Çalışma bulgularımız, Devrim'in (29) hemşirelik öğrencilerinde yaptığı çalışma sonuçlarını destekler niteliktedir. Ancak Kaya Sakarya'nın (17) üniversite ögrrencilerinde yaptığı çalışmada köyde yaşayan öğrencilerin çiftler arası şiddet kabul düzeyleri, diğer yerleşim yerlerinde (kasaba, ilçe, il) yaşayan öğrencilerinkinden anlamlı düzeyde daha yüksek bulunmuştur.

Çalışmada evde arkadaşlarıyla birlikte kalan öğrencilerin erkeğin flörtte uyguladığı psikolojik şiddete yönelik kabul düzeyleri, yurtta, ailesiyle birlikte ve diğer (akraba vb.) olarak nitelendiren yerde kalan öğrencilerinkinden anlamlı düzeyde daha yüksek bulunmuştur. Ancak kalınan yere göre erkeğin flörtte uyguladığı fiziksel şiddete yönelik, kadının flörtte uyguladığı fiziksel ve psikolojik şiddete yönelik kabul düzeyleri açısından anlamlı düzeyde bir fark saptanmamıştır. Devrim'in (29) hemşirelik öğrencilerinde yaptığı çalışmada ise öğrencilerin yaşadıkları yere göre flört şiddetine yönelik tutumlarının değişmediği belirlenmiştir.

Çalışmada kardeş sayısına göre her bir flört şiddetine yönelik kabul düzeylerinin benzer olduğu saptanmıştır. Bulgularımızın Devrim'in (29) hemşirelik bölümü öğrencilerinde ve Ayyıldız'ın (27) üniversite öğrencilerinde yaptıkları çalışma sonuçlarıyla uyumlu olduğu gözlenmiştir. İftar (19) da çalışmasında kardeşi olmayan üniversite öğrencilerinin erkeğin ve kadının flörtte uyguladıkları psikolojik şiddete yönelik kabul düzeylerinin kardeşi olan bireylerinkinden $(1,2-3, \geq 4)$ anlamlı düzeyde daha yüksek olduğunu bulmuşlardır. Ancak üniversite öğrencilerinin kardeş sayısına göre erkeğin ve kadının flörtte uyguladıkları fiziksel şiddete yönelik kabul düzeylerinin benzer olduğunu saptamıştır. Yıldırım (20) ise üniversite öğrencilerinde yaptığı çalışmada tek kardeşi olanların birden fazla kardeşi olanlara $(2, \geq 3)$ göre anlamlı düzeyde flört şiddetini desteklemeyen bir tutum sergilediklerini belirlemiştir. Buna göre bulgularımızın İftar'ın (19) çalışma sonuçlarıyla kısmen uyumlu olduğu ancak Yıldırım'ın (20) çalışma sonuçlarıyla uyumlu olmadığı söylenebilir.

Tek ebeveynli öğrencilerin erkeğin flörtte uyguladığı psikolojik şiddete yönelik kabul düzeyleri, çekirdek ve geniş ailelere sahip öğrencilerinkinden anlamlı düzeyde daha düşük bulunmuştur. Ancak aile tipine göre erkeğin flörtte uyguladığı fiziksel şiddete yönelik, kadının flörtte uyguladığı fiziksel ve psikolojik şiddete yönelik kabul düzeyleri bakımından anlamlı düzeyde bir fark bulunmamıştır. Çalışma bulgularımızın tam aksine İftar'ın (19) çalışmasında ise parçalanmış aileye sahip öğrencilerin hem erkeğin hem de kadının flörtte uyguladığı psikolojik ve fiziksel şiddete yönelik kabul düzeylerinin çekirdek ve geniş ailelere sahip bireylerinkinden anlamlı düzeyde daha yüksek bulunmuştur.

Araştırmada anne ve babanın eğitim düzeylerine göre her bir flört şiddetine yönelik kabul düzeylerinin benzer olduğu saptanmıştır. Bu bulgularımız Devrim'in (29) hemşirelik öğrencilerinde, Şahin ve Arslan'ın (25) sosyal hizmet bölümü öğrencilerinde (anne eğitim düzeyi için) ve İftar'ın (19) üniversite öğrencilerinde yaptıkları çalışma sonuçlarıyla benzerlik göstermektedir. Ayyıldız ve Taylan'ın (21) çalışmasında ise annesi ilkokul mezunu olan üniversite öğrencilerinin erkeğin flörtte uyguladığı psikolojik ve fiziksel şiddete yönelik kabul düzeyleri, annesi lise mezunu olanlarınkinden anlamlı düzeyde daha yüksek bulunmuştur. Ayrıca annesi ilkokul mezunu olan üniversite öğrencilerinin erkeğin flörtte uyguladığı fiziksel şiddete yönelik kabul düzeyi, annesi meslek yüksekokulu (MYO)/fakülte/lisansüstü mezunu 
olanlarınkinden anlamlı düzeyde daha yüksek bulunmuştur. Yine aynı çalışmada (21) babası ilkokul mezunu olan üniversite öğrencilerinin erkeğin flörtte uyguladığı fiziksel şiddete yönelik kabul düzeylerinin, babası lise ve $\mathrm{MYO} /$ fakülte/lisansüstü mezunu olanlarınkinden anlamlı düzeyde daha yüksek olduğu saptanmıştır. Ancak bizim çalışma bulgularımıza benzer şekilde Ayyıldız ve Taylan (21) da anne ve babanın eğitim düzeylerine göre kadının flörtte uyguladığ psikolojik ve fiziksel şiddete yönelik kabul düzeylerinin benzer olduğunu, ek olarak babanın eğitim düzeyine göre erkeğin flörtte uyguladığı psikolojik şiddete yönelik kabul düzeyleri arasında anlamlı düzeyde bir fark olmadığını bulmuşlardır. Şahin ve Arslan'ın (25) sosyal hizmet bölümü öğrencilerinde yaptıkları çalışmada babası ortaöğrenim mezunu öğrencilerin çiftler arası şiddeti kabul düzeyleri diğer öğrencilere (ilköğrenim ve altı, lise, üniversite ve üstü) göre daha düşük saptanmıştır. Yıldırım (20) ise üniversite öğrencilerinde yaptığ çalışmada annesi üniversite mezunu olan öğrencilerin, annesi ortaokul ve ilkokul mezunu olanlara göre anlamlı düzeyde flört şiddetini desteklemeyen bir tutum sergilediklerini belirlemiştir. Ayrıca Kaya Sakarya'nın (17) üniversite öğrencilerinde yaptığı çalışmada annesi okuryazar olmayan öğrencilerin çiftler arası şiddeti kabul düzeyleri, annesi ilkokul, lise ve dengi, ortaokul, yükseköğretim, okuryazar ancak ilkokul mezunu olmayan öğrencilerinkinden anlamlı düzeyde daha yüksek bulunmuştur. Aynı çalışmada babası okuryazar ancak ilkokul mezunu olmayan öğrencilerin çiftler arası şiddeti kabul düzeylerinin, babası ilkokul, lise ve dengi, ortaokul, yükseköğretim, okuryazar olmayan öğrencilerinkinden anlamlı düzeyde daha yüksek olduğu belirlenmiştir. Çalışma bulgularımızın literatürle kısmen benzerlik gösterdiği söylenebilir.

Çalışmada aile geliri giderinden az olan öğrencilerin kadının flörtte uyguladığı psikolojik şiddete yönelik kabul düzeylerinin, geliri giderine denk olan öğrencilerinkinden anlamlı düzeyde daha yüksek olduğu saptanmıştır. Ancak ailenin gelir düzeyine göre kadının flörtte uyguladığı fiziksel şiddete yönelik ve erkeğin flörtte uyguladığı psikolojik ve fiziksel şiddete yönelik kabul düzeylerinin benzer olduğu bulunmuştur. Şahin ve Arslan'ın (25) sosyal hizmet bölümü öğrencilerinde, Ayyıldız (27) ve İftar'ın (19) üniversite öğrencilerinde yaptıkları çalışmalarda ailenin gelir düzeyine göre her bir flört şiddetine yönelik/çiftler arası şiddet kabul düzeyleri açısından anlamlı düzeyde bir fark olmadığı saptanmıştır. Ayrıca Devrim'in (29) hemşirelik öğrencilerinde yaptığ çalışmada ailenin gelir düzeyine göre öğrencilerin flört şiddetine yönelik tutumlarının farklılaşmadı̆̆ belirlenmiştir. Ancak Kaya Sakarya'nın (17) üniversite öğrencilerinde yaptığı çalışmada aile geliri düşük olan öğrencilerin çiftler arası şiddet kabul düzeyleri, aile geliri orta ve yüksek olan öğrencilerinkinden anlamlı düzeyde daha yüksek olduğu bulunmuştur. Ayrıca Anderson ve ark.'nın (13) Çin'de üniversite öğrencileri üzerinde yaptıkları çalışmada aile gelir düzeyi ile sadece kadının flörtte uyguladığı fiziksel şiddete yönelik kabul düzeyi arasında anlamlı düzeyde negatif bir ilişki saptarlarken diğer flört şiddetine yönelik kabul düzeyleri arasında anlamlı bir ilişki saptamamışlardır. Çalışma bulgularımızın literatürle kısmen benzerlik gösterdiği söylenebilir.

Araştırmada öğrencilerin flört ilişki durumuna göre her bir flört şiddetine yönelik kabul düzeylerinin farklı

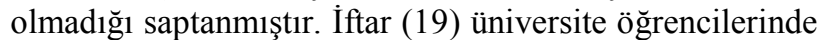
yaptığ 1 çalışmada öğrencilerin flört ilişki durumuna göre her bir flört şiddetine yönelik kabul düzeylerinin farklı olmadığını bulmuştur. Devrim'in (29) hemşirelik öğrencilerinde, Yildırım (20), Karabacak ve Çetinkaya'nın (18) ve Kaya Sakarya'nın (17) üniversite öğrencilerinde yaptıkları çalışmalarda öğrencilerin flört ilişki durumuna göre flört şiddetine/çiftler arası şiddete yönelik tutumlarının benzer olduğunu belirlemişlerdir. Özdere (28) ise beden eğitimi ve spor yüksekokulu öğrencilerinde yaptığı çalışmada flört ilișki durumuna göre erkeğin ve kadının flörtte uyguladıkları psikolojik şiddete yönelik kabul düzeylerinin benzer olduğunu saptamıştır. Ancak aynı çalışmada flört ilişkisi olmayan bireylerin erkeğin ve kadının flörtte uyguladıkları fiziksel şiddete yönelik kabul düzeyleri, flört ilişkisi olan bireylerinkinden anlamlı düzeyde daha yüksek bulunmuştur. Doğan'ın (23) erkek üniversite öğrencilerinde yaptığ 1 çalışmada erkek öğrencilerin flörtte uygulanan psikolojik ve fiziksel şiddete yönelik tutumlarının flört ilişki durumuna göre anlamlı bir farklılık göstermediği saptanmıştır. Bizim çalışmamızda da flört ilişkisi olan ve olmayan erkek öğrencilerin flörtte uygulanan hem psikolojik ve hem fiziksel şiddete yönelik tutumlarının farklılaşmadığ bulgularımızın, Ifftar'ın (19), Devrim'in (29), Yildırım'ın (20), Karabacak ve Çetinkaya'nın (18), Kaya Sakarya'nın (17) ve Doğan'ın (23) çalışma sonuçlarıyla uyumlu olduğu, Özdere'nin (28) çalışma sonuçlarıyla kısmen uyumlu olduğu söylenebilir.

Çalışmada öğrencilerin flört ilişkilerinde şiddete maruz kalma durumuna göre her bir flört şiddetine yönelik kabul düzeylerinin farklı olmadığı saptanmıştır. Özdere (28) de beden eğitimi ve spor yüksekokulu öğrencilerinde yaptığ çalışmada flört ilişkilerinde şiddete maruz kalma durumuna göre erkeğin flörtte uyguladığı psikolojik ve fiziksel şiddete yönelik kabul düzeylerinin benzer olduğunu saptamıştır. Ancak aynı çalışmada flört ilişkilerinde şiddete maruz kalan bireylerin kadının flörtte uyguladığı psikolojik ve fiziksel şiddete yönelik kabul düzeylerinin, maruz kalmayan bireylerinkinden anlamlı düzeyde daha yüksek olduğu bulunmuştur. İftar (19) üniversite öğrencilerinde yaptığ 1 çalışmada öğrencilerin geçmişte flört ilişkisinde şiddete maruz kalma durumuna göre her bir flört şiddetine yönelik kabul düzeylerinin benzer olduğunu bulmuştur. Ancak aynı çalışmada şimdiki flört ilişkisinde şiddete maruz kalanların, erkeğin flörtte uyguladığı psikolojik şiddete yönelik kabul düzeyi dışında her bir flört şiddetine (erkeğin flörtte uyguladığı fiziksel şiddet, kadının flörtte uyguladığı psikolojik ve fiziksel şiddet) yönelik kabul düzeylerinin şimdiki flört ilişkisinde şiddete maruz kalmayanlarınkinden anlamlı düzeyde daha yüksek olduğu belirlenmiştir. Doğan'ın (23) erkek üniversite öğrencilerinde yaptı̆̆ çalışmada erkek öğrencilerin flörtte uygulanan psikolojik ve fiziksel şiddete yönelik tutumlarının şimdiye kadar flört ilişkisinde şiddete maruz kalma durumuna göre anlamlı bir farklılık göstermediği saptanmıştır. Devrim (29) 
çalıșmasında flört ilişkilerinde şiddete maruz kalan hemşirelik öğrencilerinin, maruz kalmayanlara göre anlamlı düzeyde flört şiddetini desteklemeyen bir tutum sergilediklerini belirlemiştir. Yıldırım (20) üniversite öğrencilerinde yaptı̆̆ ilişkilerinde şiddete maruz kalma durumuna göre flört şiddetine yönelik tutumlarının benzer olduğunu belirlemişlerdir. Bizim çalışmamızda da şimdiye kadar flört ilişkisinde şiddete maruz kalan ve kalmayan erkek öğrencilerin flörtte uygulanan hem psikolojik ve hem fiziksel şiddete yönelik tutumlarının farklılaşmadığı saptanmıştır. Buna göre araştırma bulgularımızın, Doğan'ın (23), Yıldırım'ın (20) çalışma sonuçlarıyla benzerlik gösterdiğini, Özdere'nin (28) ve İftar'ın (19) çalışma sonuçlarıyla kısmen benzerlik gösterdiğini ancak Devrim'in (29) çalışma sonuçlarıyla benzerlik göstermediğini söyleyebiliriz.

Araştırmada öğrencilerin flört ilişkilerinde şiddet uygulama durumuna göre her bir flört şiddetine yönelik kabul düzeylerinin farklı olmadığı saptanmıştır. Özdere (28) beden eğitimi ve spor yüksekokulu öğrencilerinde ve İftar (19) üniversite ögrrencilerinde yaptıkları çalışmalarda flört ilişkisinde şiddet uygulama durumuna göre erkeğin ve kadının flörtte uyguladığı psikolojik şiddete yönelik kabul düzeylerinin ve kadının flörtte uyguladığı fiziksel şiddete yönelik kabul düzeylerinin benzer olduğunu saptamışlardır. Ancak İftar (19) şimdiki flört ilişkisinde şiddet uygulayan bireylerin erkeğin flörtte uyguladığ fiziksel şiddete yönelik kabul düzeyinin, flört ilişkisinde şiddet uygulamayan bireylerinkinden anlamlı düzeyde daha yüksek olduğunu bulmuştur. Ayrıca aynı çalışmalarda geçmişte flört ilişkisinde şiddet uygulayan öğrencilerin erkeğin ve kadının flörtte uyguladığı fiziksel ve psikolojik şiddete yönelik kabul düzeylerinin, şiddet uygulamayan öğrencilerinkinden anlamlı düzeyde daha yüksek olduğu bulunmuştur. Devrim'in (29) hemşirelik öğrencilerinde yaptığı çalışmada öğrencilerin şiddet uygulama durumuna göre flört şiddetine yönelik tutumlarının değişmediği belirlenmiştir. Doğan'ın (23) erkek üniversite öğrencilerinde yaptığı çalışmada erkek öğrencilerin flörtte uygulanan psikolojik ve fiziksel şiddete yönelik tutumlarının flört ilişkilerinde şiddet uygulama durumuna göre anlamlı bir farklılık göstermediğini saptamıştır. Yıldırım (20) ise flört ilişkilerinde şiddet uygulayan üniversite öğrencilerin uygulamayanlara göre flört şiddetini daha fazla destekleyici bir tutum içinde olduklarını belirlemiştir. Bizim çalışmamızda da flört ilişkilerinde şiddet uygulayan ve uygulamayan erkek öğrencilerin flörtte uygulanan hem psikolojik ve hem fiziksel şiddete yönelik tutumlarının farklılaşmadığı saptanmıştır. Buna göre araştırma bulgularımızın, Devrim'in (29) ve Doğan'ın (23) çalışma sonuçlarıyla uyumlu olduğu, Özdere'nin (28), İftar'ın (19) çalışma sonuçlarıyla kısmen uyumlu olduğu ve Yıldırım'ın (20) çalışma sonuçlarıyla ise uyumlu olmadığını söyleyebiliriz.

Çalışmada öğrencilerin aile içi şiddete maruz kalma durumuna göre her bir flört şiddetine yönelik kabul düzeylerinin farklı olmadığı saptanmıştır. Devrim'in (29) hemşirelik öğrencilerinde ve Yıldırım'ın (19) üniversite öğrencilerinde yaptıkları çalışmalarda öğrencilerin aile içi şiddete maruz kalma durumuna göre flört şiddetine yönelik tutumlarının benzer olduğunu belirlemişlerdir.
İftar'ın (19), Karabacak ve Çetinkaya'nın (18) üniversite öğrencilerinde yaptıkları çalışmalarda aile içi şiddete maruz kalanların her bir flört şiddetine yönelik/çiftler arası şiddet kabul düzeylerinin aile içi şiddete maruz kalmayanlarınkinden anlamlı düzeyde daha yüksek olduğu belirlenmiştir. Doğan'ın (23) erkek üniversite öğrencilerinde yaptığı çalışmada erkek öğrencilerin flörtte uygulanan psikolojik ve fiziksel şiddete yönelik tutumlarının aile içi şiddete maruz kalma durumuna göre anlamlı bir farklılık göstermediği saptanmıştır. Bizim çalışmamızda da aile içi şiddete maruz kalan ve kalmayan erkek ögrrencilerin flörtte uygulanan hem psikolojik ve hem fiziksel şiddete yönelik tutumlarının farklılaşmadığ 1 saptanmıştır. Buna göre araştırma bulgularımızın, Devrim'in (29), Doğan'ın (23) ve Yıldırım'ın (20) çalışma sonuçlarıyla benzerlik gösterdiğini ancak İftar'ın (19), Karabacak ve Çetinkaya'nın (18) çalışmalarıyla benzerlik göstermediğini söyleyebiliriz.

Ayrıca Selçuk, Avcı ve Mercan'ın (24) üniversite öğrencilerinde yaptıkları çalışmada geçmişte psikolojik şiddet gören ve görmeyen öğrencilerin flörtte uygulanan her bir şiddete yönelik tutumlarının da benzer olduğunu; geçmişte fiziksel şiddet gören ve görmeyen öğrencilerin kadının flört ilişkisinde uyguladığı psikolojik ve fiziksel şiddete yönelik kabul düzeyleri arasında fark olmadığını saptamışlardır. Ancak aynı çalışmada geçmişte fiziksel şiddet gören bireylerin erkeğin flört ilişkisinde uyguladığı psikolojik ve fiziksel şiddete yönelik kabul düzeylerinin, geçmişte fiziksel şiddet görmeyen bireylerinkinden anlamlı düzeyde daha yüksek olduğunu belirlemişlerdir. $\mathrm{Bu}$ bulgular açısından araştırmamızda flört ilişkisinde ya da aile içinde şiddete maruz kalma durumuna göre flörtte uygulanan her bir şiddete yönelik tutumlara ait elde ettiğimiz sonuçlarla kısmen de olsa benzerlik gösterdiğini söyleyebiliriz.

Çalışmamızda aile içi şiddete maruz kalan $(\% 18,4)$ ve kalmayan $(\% 13,3)$ bireylerde şu ana kadar flört ilişkisinde şiddet uyguladığını düşünenlerin oranları arasında anlamlı düzeyde fark saptanmazken, aile içi şiddete maruz kalmayan bireylerin şu ana kadar flört ilişkisinde şiddet uygulamadığını düşünenlerin oranı (\%75), aile içi şiddete maruz kalanlarda gözlenen orandan $(\% 55,3)$ anlamlı düzeyde daha yüksek bulunmuştur. Özdere (28) ise çalışmasında evde şiddete maruz kalma durumu ile ilişkide şiddete başvurma durumu arasında anlamlı düzeyde bir ilişki saptamıştır ve çocuklukta yaşanan şiddetin bireylerin ileriki yaşamlarında şiddete meyilli hale gelmelerine neden olabileceğini söylemiştir.

$\mathrm{Bu}$ çalışmayla üniversite öğrencilerinin flört şiddetine yönelik tutum ve davranışları belirlenerek, şiddete yönelik olumsuz tutum ve davranışlarının olumlu yönde değiştirilmesi için yapılacak planlamalara katkı sağlanacağı düşünülmektedir. Özellikle şiddetten uzak bir toplumun yetişmesi için bireylerin ergenlik döneminde öğrenim gördükleri okullarda ya da danışmanlık/tedavi merkezlerinde genel şiddet ve flört şiddetiyle ilgili bilgilendirme ve farkındalık çalışmalarının yapılmasını önermekteyiz

Yazarların Katkıları: Fikir/Kavram: Ş.C., T.B., B.T., S.O., F.D., S.K., B.A., M.G., B.T., B.D.; Tasarım: Ş.C.; Veri Toplama: T.B., B.T., S.O., F.D., S.K., B.A., M.G., 
B.T., B.D.; Analiz ve Yorum: S.C.; Literatür Taraması: Ş.C., T.B., B.T., S.O., F.D., S.K., B.A., M.G., B.T., B.D.; Makale Yazımı: Ş.C., T.B., B.T., S.O., F.D., S.K., B.A., M.G., B.T., B.D.; Eleştirel İnceleme: Ş.C.

\section{KAYNAKLAR}

1. Aslan D, Vefikuluçay D, Zeyneloğlu S, Erdost T, Temel F. Ankara'da iki hemşirelik yüksekokulunun birinci ve dördüncü sınıflarında okuyan öğrencilerinin flört şiddetine maruz kalma, flört İlişkilerinde şiddet uygulama durumlarının ve bu konudaki görüşlerinin saptanması araştırması. Teknik rapor. Ankara: Hacettepe Üniversitesi Kadın Sorunları Araştırma Merkezi ve HASAK; 2008.

2. Callahan MR, Tolman RM, Saunders DG. Adolescent dating violence victimization and psychological wellbeing. Journal of Adolescent Research. 2003; 18(6): 664-81.

3. Kılınçer A, Tuzgöl Dost M. Üniversite öğrencilerinin romantik ilişkilerinde algıladıkları istismar. Türk Psikolojik Danışma ve Rehberlik Dergisi. 2014; 5(42): 160-72.

4. Harcar T, Çakır Ö, Sürgevil O, Budak G. Kadına yönelik şiddet ve Türkiye'de kadına yönelik şiddetin durumu. Toplum ve Demokrasi. 2008; 2(4): 51-70.

5. Çakır Koçak Y, Öztürk Can H. Flört şiddeti: tanımı, sınıflaması ve değerlendirmesi. Özbaşaran F, editör. Toplumsal cinsiyet ve kadın. Ankara: Türkiye Klinikleri; 2019. s.43-53.

6. Martins C, Gouveia A, Chaves M, Lourenço R, Marques S, Santos T. Dating violence and nursing student well-being. Aten Primaria. 2014; 46(Suppl 5): 129-34. 6567(14)70079-4.

7. Akcan G. Flört şiddeti: psikopatolojik bir değerlendirme. Bartın Üniversitesi Edebiyat Fakültesi Dergisi. 2020; 5(2): 72-87.

8. Kütük EK, Gümüştaş F, Almiş BH. Üniversite öğrencisi kızlarda flört şiddetinin belirleyicileri ve psikiyatrik sonuçlar açısından flört dışı şiddetten farklılıkları. Anadolu Psikiyatri Dergisi. 2018; 19(2): 217-22.

9. Kisa S, Zeyneloglu S. Perceptions and predictors of dating violence among nursing and midwifery students. Journal of Advanced Nursing. 2019; 75(10): 2099-109.

10. Holt M, Espelage D. Social support as a moderator between dating violence victimization and depression/anxiety among African American and Caucasian adolescents. Schol Psychology Rewiew. 2005; 34(3): 309-28.

11. Amar AF, Gennaro S. Dating violence in college women: associated physical injury, healthcare usage, and mental health symptoms. Nursing Research. 2005; 54(4): 235-42.

12. Banyard VL, Cross C. Consequences of teen dating violence: understanding intervening variables in ecological context. Violence Against Women. 2008; 14(9): 998-1013.

13. Anderson JR, Chen WC, Johnson MD, Lyon SE, Lee $\mathrm{CY}$, Zheng F, et al. Attitudes toward dating violence among college students in mainland China: an exploratory study. Violence Vict. 2011; 26(5): 63147.

14. Oswalt SB, Wyatt TJ, Ochoa Y. Sexual assault is just the tip of the iceberg: relationship and sexual violence prevalence in college students. Journal of College Student Psychotherapy. 2018; 32(2): 93-109.

15. Biçer S, Demir G. Üniversite öğrencilerinin flört şiddetine maruz kalma durumları ve etkileyen faktörler. Turkish Studies. 2017; 12(13): 171-88.

16. Akış N, Korkmaz NH, Taneri PE, Özkaya G, Güney E. Üniversite öğrencilerinde flört şiddeti sıklığı ve etkileyen etmenler. ESTÜDAM Halk Sağlığı Dergisi. 2019; 4(3): 294-300

17. Kaya Sakarya A. Üniversitede öğrenim gören gençlerde flörtte şiddet [Yüksek Lisans Tezi]. Konya: Necmettin Erbakan Üniversitesi Eğitim Bilimleri Enstitüsü, Eğitim Bilimleri Anabilim Dalı, Psikolojik Danışmanlık ve Rehberlik Bilim Dalı; 2013.

18. Karabacak A, Çetinkaya SK. Üniversite öğrencilerinin şiddet kabul düzeylerinin çeşitli değişkenler açısından incelenmesi. Eğitim Kuram ve Uygulama Araştırmaları Dergisi. 2015; 1(1): 13-21.

19. İftar M. Üniversite öğrencilerinin flört şiddetine yönelik tutum ve davranışları [Yüksek Lisans Tezi]. Muğla: Muğla Sitkı Koçman Üniversitesi Sağlık Bilimleri Enstitüsü, Hemşirelik Anabilim Dalı; 2016.

20. Yıldırım S. Üniversite öğrencilerinin benlik saygısı ve toplumsal cinsiyet tutumlarının flört şiddetine yönelik tutumlarına etkisi [Yüksek Lisans Tezi]. Ankara: Hacettepe Üniversitesi Sağlık Bilimleri Enstitüsü, Doğum ve Kadın Hastalıkları Hemşireliği; 2016.

21. Ayyıldız AB, Taylan HH. Üniversite öğrencilerinde flört şiddeti tutumları: Sakarya üniversitesi örneği. Akademik Sosyal Araştırmalar Dergisi. 2018; 6(86): 413-27.

22. Şimşek GF, Kavas AB. Flört şiddetine yönelik tutum, toplumsal cinsiyet ve benlik saygısı arasındaki ilişkilerin incelenmesi. Gür M, Güneş MŞ, Bilen Ö, editörler. Aile eksenli şiddetten sosyal travmalara. Ankara: HEGEM Yayınları; 2018. s. 158-72. ISBN: 978-975-2489-11-0.

23. Doğan S. Erkeklik rollerini kabullenmenin ve erkekliğe yönelik tehdit algısının üniversite öğrencilerinin flört şiddetine yönelik tutumları ile ilişkisi [Yüksek Lisans Tezi]. Gaziantep: Gaziantep Üniversitesi Eğitim Bilimleri Enstitüsü, Eğitim Bilimleri Anabilim Dalı; 2018.

24. Selçuk KT, Avcı D, Mercan Y. Üniversite öğrencilerinde flört şiddetine maruziyet: flört şiddetine yönelik tutumların ve toplumsal cinsiyet algısının şiddete maruziyet ile ilişkisi. ACU Sağlık Bil Derg. 2018; 9(3): 302-8.

25. Şahin H, Arslan K. Sosyal hizmet bölümü öğrencilerinin çiftler arası şiddeti kabul düzeylerinin çeşitli değişkenlere göre incelenmesi. 4. Uluslararası Farklı Şiddet Boyutları ve Toplumsal Alg1 Kongresi; 10-11 Aralık 2018, İstanbul. İstanbul: Güven Plus Grup Danışmanlık A.Ş. Yayınları; s. 41-8.

26. Sezer Ö, Sumbas E. Üniversite öğrencilerinin çiftler arası şiddeti kabullerinin çeşitli değişkenler açısından incelenmesi. Uluslararası Sosyal Araştırmalar Dergisi. 2018; 11(56): 638-49. 
27. Ayyıldız AB. Üniversite öğrencilerinin flört şiddetine yönelik tutumları: Sakarya Üniversitesi örneği [Yüksek Lisans Tezi]. Sakarya: Sakarya Üniversitesi Sosyal Bilimler Enstitüsü, Sosyal Hizmetler Anabilim Dalı; 2019.

28. Özdere M. Üniversite öğrencilerinin flört şiddetine ilişkin tutumları. Akademik Sosyal Araştırmalar Dergisi. 2019; 7(95): 314-31.

29. Devrim SB. Hemşirelik öğrencilerinin toplumsal cinsiyet algısının flört şiddeti tutumuna etkisi [Yüksek Lisans Tezi]. İstanbul: İstanbul Okan Üniversitesi Sağlık Bilimleri Enstitüsü, Hemşirelik Anabilim Dalı; 2019.

30. Price EL, Byers ES, Belliveau N, Bonner R, Caron B, Doiron $\mathrm{D}$, et al. The attitudes towards dating violence scales: development and initial validation. Journal of Family Violence. 1999; 14(4): 351-75.

31. Yumuşak A, Şahin R. Flörtte şiddete yönelik tutum ölçeklerinin güvenirlik ve geçerlik çalışması. Elektronik Sosyal Bilimler Dergisi. 2014; 13(49): 233-52. 